\title{
The 'unachieved' place of art education in the South
}

\author{
Rita Emanuela Rainho Brás \\ PhD in Arts Education, FBAUP, Portugal \\ Integrated Researcher in i2ADS - Research Institute in Art, Design \\ and Society, FBAUP - Faculty of Fine Arts \\ University of Porto - FBAUP \\ ritaemanuelarainhobras@gmail.com
}

\author{
Ana Reis \\ Collaborating Researcher at i2ADS - Art, Design and Society Resear- \\ ch Institute, FBAUP \\ Faculty of Fine Arts, UP-University of Porto - FBAUP \\ PhD Student in Artistic Education, Master in Visual Arts Teaching by \\ FPCEUP - Faculty of Psychology and \\ Educational Sciences, UP \\ anareis.arq@gmail.com
}

\begin{abstract}
This article introduces the Ph.D. studies of its authors, who put into question the bridge between utopia and the reality experienced at the Mindelo_International School of Art (Mindelo_Escola Internacional de Arte - M_EIA), legally known as the University Institute of Art, Technology, and Culture [Instituto Universitário de Arte, Tecnologia e Cultura], the first Higher Education space in the areas of arts and design in Cape Verde, constituting a singular, irreverent, project in the struggle for art education practices informed by decolonized policies. Created in 2004, this utopian project sent its anchors out to the practices, promoting the country's culture and development, by means of a relationship with the Atelier Mar's local development projects, consolidating a long experience in the art education area. Tensions arise between expectations about the experimental and local nature of the M_EIA and its regulation and (non-)conformity with hegemonic knowledge in art education or development models foreign to the Cape Verdean reality.
\end{abstract}

Key words art education; utopian project; unachievement.

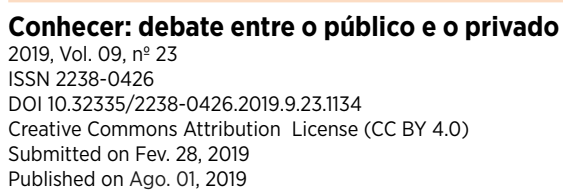




\section{O lugar "desconseguido" da educação artística no Sul Resumo}

Este artigo apresenta as pesquisas de doutoramento de suas autoras, que questionam a ponte entre a utopia e a realidade vivenciada na Mindelo_Escola Internacional de Arte (M_EIA), reconhecida juridicamente como Instituto Universitário de Arte, Tecnologia e Cultura, o primeiro espaço de Ensino Superior nas áreas das artes e do design em Cabo Verde, constituindo um projeto singular, irreverente, na luta por práticas de educação artística informadas por políticas descolonizadas. Criado em 2004, esse projeto utópico lança suas âncoras às práticas, promovendo a cultura e o desenvolvimento do país, por meio de uma relação com os projetos de desenvolvimento local do Atelier Mar, consolidando a longa experiência na área da educação artística. As tensões surgem entre as expectativas sobre o carácter experimental e local da M_ElA e sua regulamentação e (não) conformidade com o conhecimento hegemónico em educação artística ou os modelos de desenvolvimento estranhos à realidade cabo-verdiana.

Palavras-chave educação artística; projeto utópico; desconseguimento.

\section{El lugar "desconseguido" de la educación artística en el Sur Resumen}

Este artículo presenta las investigaciones de doctorado de sus autoras, que cuestionan el puente entre la utopía y la realidad vivenciada en la Mindelo_Escuela Internacional de Arte (Mindelo_Escola Internacional de Arte - M_EIA), legalmente reconocida como Instituto Universitario de Arte, Tecnología y Cultura [Instituto Universitário de Arte, Tecnologia e Cultura], el primer espacio de Educación Superior en las áreas de arte y design en Cabo Verde, constituyendo un proyecto singular, irreverente, en la lucha por prácticas de educación artística informadas por políticas descolonizadas. Creado en 2004, este proyecto utópico lanza sus anclas a las prácticas, promoviendo la cultura y el desarrollo del país, a través de una relación con los proyectos de desarrollo local del Atelier Mar, consolidando una larga experiencia en el área de educación artística. Las tensiones surgen entre las expectativas sobre el carácter experimental y local de la M_EIA y su reglamentación y (no) conformidad con el conocimiento hegemónico en educación artística o los modelos de desarrollo ajenos a la realidad caboverdiana.

Palabras clave educación artística; proyecto utópico; desconseguimiento.

\section{Le lieu « non atteint » de l'éducation artistique au Sud}

\section{Résumé}

Cet article présente les recherches doctorales de ses auteurs, qui questionnent le pont entre l'utopie et la réalité vécue à la Mindelo_École Internationale d’Art (Mindelo_Escola Internacional de Arte - M_EIA), légalement reconnu comme Institut Universitaire d'Art, de Technologie et de Culture [Instituto Universitário de Arte, Tecnologia e Cultura], le premier espace de l'Enseignement Supérieur dans les domaines des arts et du design au Cap-Vert, constituant un projet singulier, irrévérencieux, dans la lutte pour des pratiques d'éducation artistique inspirées par des politiques décolonisées. Créé en 2004, ce projet utopique lance ses ancres dans les pratiques, promouvant la culture et le développement du pays, à travers une relation avec les projets de développement local de l'Atelier Mar, consolidant sa longue expérience dans le domaine de l'éducation artistique. Des tensions apparaissent entre les attentes concernant le caractère expérimental et local de la M_EIA et sa réglementation et le (non-)conformité avec les connaissances hégémoniques en éducation artistique ou avec des modèles de développement étrangers à la réalité cap-verdienne.

Mots-clés éducation artistique; projet utopique; non-atteint. 


\section{Background}

The authors of this article have pursued their Ph.D. studies at the Mindelo_ International School of Art (Mindelo_Escola Internacional de Arte - M_EIA), legally known as the University Institute of Art, Technology, and Culture [Instituto Universitário de Arte, Tecnologia e Cultura], an art school created by Atelier Mar, a Cape Verdean non-governmental organization (NGO). Atelier Mar emerged at a historical moment defined by a one-party regime installed after the end of Portuguese colonization (Cape Verde gained independence in 1975). The mission of this NGO was clearly identified with the idea of reconstructing the country, as well as tackling the effects of the post-independence regime - African Party for the Independence of Guinea and Cape Verde (Partido Africano para a Independência da Guiné e Cabo Verde - PAIGC). Its action over time was grounded in both culture and development (with considerable contribution to professional qualification in arts and crafts and community development).

The M_EIA was created in 2004, as a singular project due to its irreverence in the struggle for deploying decolonized policies and practices in art education. Consolidating the experience of the Atelier Mar and committed to sustainable local development, the M_EIA brings its learning process into the communities, feeds on local knowledge, aiming to participate in the country's development. The M_EIA goes beyond subject boundaries, working through projects to which many knowledge areas contribute and it escapes the traditional school spaces and schedules. In close contact with Cape Verdean identity and reality, the M_EIA does not reject 'Western' knowledge, but this is addressed in projects along with local practices, appreciating the human and material resources available to seek better and fairer ways of living.

\section{Who we are and how we stand and work}

The proposal of this article is presenting our Ph.D. studies in art education, which put into question the bridge between utopia and the reality experienced at the M_EIA, in order to understand how utopia influences everyday practices. Both of us resorted to narratives of people involved in the project, with multiple and diverse subjectivities, and to our own personal experiences as teachers and researchers.

We decided to displace ourselves from our (un)comfort(able) zone, strongly legitimated by Western thought; a comfort zone because this corresponds to what is already known to us, but also an uncomfortable zone due to the awareness of its colonizing power. We wished to face the unknown, the danger zone of a utopian project, believing that the place of a foreigner - who does not know the country, the local reality, and above all how to play a role in building this project - would push us towards challenging reflections 
and in-depth discussions of alternatives. The freshness of that utopian place, allied to a fragility standpoint, put our reality into question and provides us with a privileged view, as Greene (1995, p. 83, our translation) claims:

\footnotetext{
In everyday reality, to put ourselves in the advantageous position of a foreigner means being able to look perplexedly and interrogatively at the world in which we live. It is like coming home after a long stay anywhere else. The person who returns home perceives in his/her environment details and shapes that he/she has never seen before: he/she discovers the need to rethink the rituals and customs of his/her people to grasp them.
}

The methodology adopted herein takes as its key principle a critical reflection based on our practices as teachers working at this specific school and context, facing the everyday challenges of a university institute, and not only as scholars who observe from afar the educational practices taking place. So, our perspective is deeply embedded and rooted on our personal and collective experiences, although we inevitably diverge with regard to our educational work and our viewpoint as researchers.

\section{The utopian project and its aims}

The M_EIA is not generally described or mentioned as a utopia. It is often referred to as a laboratory and an ongoing project. During our studies, both of us arrived at this non-existent (from the Greek 'óu' + 'topos') or perfect place (also from the Greek 'eu' + 'topos'). We started our quest by feeling that the schools we knew were not desirable places; thus, we wished to investigate if there was still a possibility to play a role at a school that asks questions about itself and its mission, goals, organization, contents, and context, as well as what its members (both teachers and students) desire.

Being aware of this project through its author's words and images, we were fascinated and intrigued by something that looked like a dream world where communities, both inside and outside the school gates, got involved in projects that aim at contributing to culture and arts with a view to local development. On this utopian discourse, we believe, lies the origin of the school's mission, even if daily struggles and controversies lead practices to diverge from it.

The M_EIA's deployment was necessarily bifurcated into the utopian and both legal and accomplishment perspectives. The first, the utopian, sent its anchors out to the practices, thus promoting the country's development, mainly by means of relations to local development projects at Atelier Mar. The second became, on one hand, allied to the politics 
of the European Bologna model, in order to obtain national certification of the degrees, and on the other the (im)possibility of the utopian project, due to the 'unachievement' when incorporating utopia in daily practices at school. However, it raises tensions between expectations over the experimental and local nature of the M_EIA's activity and its regulation and (non-)conformity with hegemonic knowledge in art education or development models foreign to the Cape Verdean reality.

\section{Our need for utopia}

Our quest for an alternative school education started from our relation to the reality of an educational institution located in the political North, recognizing some persistent features that drive its actions.

As for knowledge structure and organization, there are geopolitical boundaries between the contents that translate knowledge transmission into pre-established standards. Thus, a categorization and a hierarchy aligned to a male Western supremacy (patriarchal Eurocentrism) become clear.

Also, we observe obsolete assessment criteria, whose instruments are mainly quantitative. They classify students according to their knowledge reproduction ability, disregarding diversity and failing to address various ways of knowing and communicating.

The detachment of academic knowledge from everyday life and the lack of interaction between disciplines (as well as the gap between theory and practice and technical and artistic applications) are also detached from contemporaneity. This scenario does not promote the relationships, interfaces, and interdependency needed for grasping and acting upon our complex social, political, economic, and cultural contexts.

\footnotetext{
To speak of reality as something still, static, compartmentalized and wellbehaved, when not speaking or lecturing about something completely foreign to the students' existential experience has been, actually, the supreme concern of this kind of education. Uncontrollable longing. There, the educator appears as an indisputable agent, like its actual subject, whose undeniable task is "filling" students with contents that he narrates. These contents are pieces of reality disconnected from the totality in which they are engendered and whose perspective may gain meaning. The word, in these dissertations, is emptied of the concrete dimension that it should have or it becomes a hollow word, in alienated and alienating verbosity. This is more sound than meaning, so it would be better not to say it (Freire, 1987, p. 33, our translation).
} 
There is still a sovereign objectivity, regarded as an exclusive knowledge production criterion, a 'truth-driven' rationale that ignores subjectivity and non-neutrality, the political side of human thought and action.

The naturalization of a logical learning sequence, as well as the domain of basic knowledge, supports teachers' belief that if students do not go through all these phases, they will not be successful. And this is translated into schools where normativity, linearity, and sequentiality reign in the teaching-learning process, disregarding the sensitive and emotional (affective) side of learning, showing to be unable to tackle diversity issues.

As far as the relationships and hierarchies between school community members are concerned, the architecture itself reflects and reinforces them, focusing on body and mind discipline. The school works as an enclosed and controlled space, modeling behaviors and learning activities, according to a dynamics that tends to come from teacher to student. A common critique to teaching-learning processes consists in their disregard for students' knowledge. Having in mind the concept of meaningful learning, as proposed by Ausubel (1960), this often results in the impossibility of connecting new knowledge to the previous and attributing meaning to it. Although participation and collaboration are keywords in contemporary discourses, they usually refer to a superficial interactivity, where roles and actions are previously determined and there is no possibility of changing rules and/or making decisions.

Focusing on the specificity of arts education, its history dates back to the Industrial Revolution, demanding both creativity and technical skills learnt in art and technology classes. Today there is still a demand to promote and improve creativity and innovation for new industries under capitalist power and control nets. So, we struggle not to comply with it.

From another perspective, art education has been used as a therapy tool to tackle social issues and problems, applied to poor and vulnerable people considered in need of salvation.

There is a modern heritage of the genius, which may produce a belief in the existence of only a few gifted individuals, to the detriment of most students. This belief in individuality and authorship contributes to the distinction between popular and fine arts - the first one is excluded from curricula. Although increasingly less importance is attributed to technical skills, there is still a concern with originality, authenticity, and mimesis - contradictory as they might be. Often, art classes become a time and space for doing exercises that constitute a simulacrum, detached from the artistic experience itself.

These and other concerns accumulate and lead us to look for alternatives. The importance of utopia lies on its potential as a driving force towards a resistance movement and it refers to our way of living, but in a non-accommodated and hopeful manner. Although utopia may be seen as something impossible, we see it as a possible 'unachievement,' a political act that keeps us aware of our activities and committed to a shared ideal. 
Thus, any utopia is born out of discomfort, estrangement, or even a crisis, in face of lack of identification with existing values, so it involves hope for a better world. It emerges in between an existing reality and another one that people wish for - so they start thinking, analyzing, and writing about it, assuming that a change is possible.

The unprecedented telluric reality for the occupants of a unique experience in the Middle Atlantic turned out to be a destination and a starting point. A land strange to all, fragmented, in the middle of a sea desert. (Lopes, 2012, 247 our translation).

Cape Verde has specificities related to the political South that we would not observe in Portugal, such as new and fragile institutions allowing rethinking and transformation, contrasting with the difficulty to intervene in a long lasting European academic tradition. Although the Cape Verdean institutions are relatively new, they still remain dominated by Western thought and action, as well as under the influence of colonialism, globalization, and capitalist discourses, depending on international legitimization and foreign financial investment. So, we observed traces of Western academic practices in Cape Verde and shed some light on this context.

\section{Institutions thinking through themselves}

Our utopia leads us to believe that institutions should think through themselves from within, thus admitting to be open and willing to change. Institutions should not standardize themselves nor aspire the Truth.

The M_EIA has a mission since its early days: combining arts, culture, and development and thinking how this can be done in face of numerous variables and constraints. Assessment procedures were adopted to reflect upon underlying assumptions through in-depth analysis.

As a university institution, the M_EIA is trapped within a set of rules, standards, and regulations. National curricular and methodological guidelines do not consider utopian political aims, like students and teachers' participation to define criteria, goals, methods, procedures, assessment and programs.

The academic underlying assumptions are based on hegemonic knowledge. Thus, non-academic contributions are disregarded because they supposedly lack scientific criteria (e.g. objectivity, rationality, and neutrality).

The M_EIA mainly addresses traditional knowledge accessed through contact with local communities, relying on data related to personal experience. It aims to go beyond geopolitical boundaries of the contents, focusing not only on the reality of other continents, countries, and cultures, but also on underrepresented peoples, neglected minorities, and 
invisibilized groups, establishing a dialogue between local or locally rescued knowledge and global advances in the areas of design, arts, and architecture.

These knowledge areas converge in a pluralist, non-discipline driven art education in order to tackle specific issues and local emergencies like sustainable architecture for water collection, and goat cheese ripening in pozzolana caves, a community school in Lajedos, as well as a laboratory for food design. Rediscovering the Cape Verdean identity and its African and European heritage may result in the creation of a transcultural study center.

Besides taking an open path to plural and diverse knowledge, our utopia deals with collectively deconstructed knowledge, establishing relationships between various areas and everyday life. This contributes to the dilution of traditional boundaries between theory and practice and technical and artistic applications.

The M_EIA translates this into a redefinition of the school environment, making fluid, flexible, and mobile experimental activities, bridging the gap between thinking and doing. There is a risk in including areas traditionally not regarded as key for the courses, such as music, cultural production, food design and literature. There is contact and exchange between students pursuing different courses, subjects and levels, artisans, and professors. Community elements play various roles at different times, especially when working through projects.

Openness, flexibility, and risk-taking attitudes are required from practitioners, professors, artisans, and others participants, i.e. sharing the school's political goals and purposes.

The M_EIA's commitment to social, political, and economic context drives its perspective on development. So, it engages in practices outside the school gates, reaching other community members, improving social skills, and the dialogue with everyday life emergencies. It is expected that students become culturally active citizens through critical thinking, local intervention, and resistance to global and capitalist concepts of development, which tend to exploit people and resources.

In order to improve students' critical thinking and intervention ability, we believe they should participate in the discussion and definition of their academic expeditions including their self-assessment, which contributes to recognizing personal and collective learning by creating suitable spaces to discuss learning processes, making people aware of the various paths and projects. Assessment should also be a major source of data for thinking through school dynamics and processes. Especially when projects are taking shape, assessment should be transversal to various areas. All of this means taking risks and defying power relations, so that academic practices rely on an experimental dimension. 


\title{
Engagement and belonging
}

\author{
"The engaged voice must never be fixed and absolute but always changing, \\ always evolving in dialogue with a world beyond itself” (Hooks, 2013, p. 22, our \\ translation).
}

Although we assume a utopia may have its origins in a single mind or a very strict group, as it persists, other people engage in it. Then, we ask when it is time to criticize, debate, think through, and rationalize the engagement needed.

Such an immersion requires sensibility and openness to individual conceptions, interests, needs, and values, as well as a diagnosis and discussion of patterns, which must. be judiciously reviewed.

This also implies democratic structures to open the path to collectively advocate the guidelines. How does an individual find her/his position in the whole context? These structures must be established through communication dynamics and engagement in management and decision-making processes at every level of the utopian project. We believe in a utopia of reasons as an alternative to a utopia of reason, i.e. a utopia open to change to be shared and cherished. Again, we ask about collectivity and diversity in utopia. When do we become part of it? To get closer to our utopia, a stronger and more compelling common desire is needed.

In the M_EIA, it seems like its small number of people may facilitate a diagnosis of various art education guidelines, communication between its members, and discussion of its utopian project, thus allowing a collectively recognized map of priorities. The informal and friendly environment of the M_EIA could be a facilitator, with shared responsibility over the issues at stake. The fact that a significant group of young professors do not stay in the institution for a long time contributes to weaken its utopian project, hindering the continuity of practices and the achievement of the school's goals, lacking knowledge and commitment to the utopia.

As the M_EIA seeks opportunities to learn along with local communities and tackle local emergencies, it seems that, as a utopian project, it should strengthen the relationships established with the 'outside'. That is, we query about local communities' chance to get involved with the projects at all of their levels including decision making. We believe there is a need to look at finished projects to relate their continuity or discontinuity to dialogues set in place. 


\section{Processes}

In the M_EIA, through context-based learning, namely urban and sensorial experimental projects, we achieve a school community approach to emerging issues, engaging in Cape Verdean reality. This implies our suspension by fully understanding issues in their context, working with local communities to reach better ways of life, departing from their needs and desires to pursue better ways of life. This means respecting otherness to look for collective solutions.

Such a perspective change highlights the relevance of popular knowledge, as a collective heritage, and students' own stories. Community intervention projects can widen students prior knowledge, drawing new horizons through meaningful learning.

Considering the relevance of various counterparts in context-based learning opens room for a utopian decolonization of thinking and doing art education:

What I am going to propose here is that we explore together another possibility, let's say a rather existential (without being existentialist) and aesthetic (with no aesthetic view), namely, think of education through the experience/sense pair (Larrosa, 2002, p. 20, our translation).

By recognizing diversity and subjectivities, the utopian art education project relies on nonlinear processes. Contrary to a logical sequence of steps, projects in M_EIA integrate, derive, and discover. This approach to the context incorporates intuition and demands attention and sensibility towards everyday life, bringing up many 'truths' in confrontation with scientific criteria.

In short, critically constructed knowledge allows a commitment with social, cultural, local and global development. Thus, the M_EIA seeks to address sensory, emotional, and kinaesthetic knowledge and resorts to visual, auditory, and tactile learning resources.

\section{Utopia is not $\mathrm{a}(\mathrm{n})(\mathrm{im})$ possible place}

As an academic institution defines its identity, is it able to include people who wish a different school? Is it possible to meet individual needs?

The proposals developed by M_EIA are challenging because of different work dynamics, namely the individual and/or the collective ones. These dynamics are crucial to the school mission and are discussed with students and local community members, during projects development, and over their implications. Such dynamics also allow us to question the tendency of thinking of author's individuality and authorship and the inheritance of arts 
education concepts on geniality and artist's training. A collectivity open to its members subjectivities may enable meaningful future interventions. In other words, collective work dynamics and project-based learning (establishing connections to a real context and community) can open room for a rather complex worldview, by addressing contradictions, fallacies, and inconsistencies. Such an approach also confronts us with the boundaries of 'scientific knowledge' and its underlying concepts and introduces the messiness of everyday life. Improving students' awareness may be claimed as a successful outcome of the M_EIA's utopian project, which is not driven by quantitative criteria.

By fostering projects kept open and allowing students to engage in discovery while acknowledging the unknown, the institution opens room for 'disobedient' ways of exploring, learning, and investigating pertinent issues.

In addition to the difficulty of engaging in risky procedures and irreverent art education in a traditionally rule-based institution (a university), the issue of meeting market and knowledge society needs (and expectations from teachers and students as future professionals) gains momentum. Constraints come up when faced with common bias among students, professors, and community members regarding artists, designers, architects, etc.

The wish for success, associated with some ideas about professional roles, involves a need for individual acknowledgement that goes against the anonymity policy of collaborative work processes - which disregard authorship. A liberal market naturalizes the need for competitiveness, crashing with associationism and cooperativism as resistance to globalization.

In such a resistance effort, the discourses about sustainable projects are highlighted, but the Cape Verdean dependence on foreign financial investment remains common sense. Is this external financial help support significant to keep the projects among local communities? What contributes to their success or failure?

Although the M_EIA depends on foreign funding, its actions for continuous local development where incorporated into the engaged communities' daily survival practices over the years.

Also, arts education practices in line with the Cape Verdean reality opens a path of continuities and discontinuities leveraged by M_EIA. Accommodating the reach for utopia, it is in doing, failing, and doing again that the action incorporates the utopian 'unachievement'.

How does the M_ElA's philosophy and this utopian project influence students and professors to better coping with their reality and their future?

The movement set by the M_EIA reflects the struggle to adopt art education practices that are not unfamiliar with the Cape Verdean reality, as well as the decolonization efforts in the political South. We will keep on fighting for the (im)possibility of the art education utopian place. 


\section{References bibliographical}

Ausubel, D. P. (1960). The use of advance organizers in the learning and retention of meaningful verbal material. Journal of Educational Psychology, 51, 267-272.

Freire, P. (1987). Pedagogia do oprimido. Rio de Janeiro, RJ: Paz e Terra.

Greene, M. (1995). El profesor como extranjero. In J. Larrosa (Ed.), Déjame que te cuente (pp. 81-130). Barcelona, España: Alertes.

Hooks, B. (2013). Ensinando a transgredir: a educação como prática da liberdade. São Paulo, SP: Martins Fontes.

Larrosa, J. B. (2002). Notas sobre a experiência e o saber de experiência. Revista Brasileira de Educação, 19, 20-28.

Lopes, L. (2012). M_EIA, um laboratório, um projecto de ensino artístico e do design em plano Atlântico Médio. In C. Martins, M. Terrasêca, \& V. Martins (Orgs.), À procura de renovações. De estratégias e de narrativas sobre educação artística (pp. 247-250). Porto, Portugal: GESTO. 


\section{How to cite this article:}

\section{ABNT}

RAINHO, R.; REIS, A. The 'unachieved' place of art education in the South. Conhecer: Debate entre $O$ Público e o Privado, v. 9, n. 23, p. 16-28, 2019.

\section{APA}

Rainho, R., \& Reis, A. (2019). The 'unachieved' place of art education in the South. Conhecer: Debate entre o Público e o Privado, 9(23), 16-28.

\section{Vancouver}

Rainho R, Reis A. The 'unachieved' place of art education in the South. Conhecer: Debate entre o Público e o Privado [Internet]. 2019 [cited Ago 1, 2019];9(23):16-28. Available from: https://revistas. uece.br/index.php/revistaconhecer/article/view/1134 